\title{
Characterization of the Terminal Iron(IV) Imides $\left\{\left[\mathrm{PhBP}^{\mathrm{tBu}}{ }_{2}(\mathrm{pz})\right]\right.$ $\left.\mathrm{Fe}^{\mathrm{Iv}} \equiv \mathrm{NAd}\right\}^{+}$
}

\author{
Christine M. Thomas, Neal P. Mankad, and Jonas C. Peters ${ }^{\star}$ \\ Division of Chemistry and Chemical Engineering, Arnold and Mabel Beckman Laboratories of \\ Chemical Synthesis, California Institute of Technology, Pasadena, California 91125.
}

\begin{abstract}
New hybrid bis(phosphine)(pyrazole)borate tripodal ligands $\left(\left[\mathrm{PhBP}^{t \mathrm{Bu}_{2}}\left(\mathrm{pz}^{\prime}\right)\right]^{-}\right)$are reported that support pseudotetrahedral iron in the oxidation states $+1,+2,+3$, and +4 . The higher oxidation states are stabilized by a terminal $\mathrm{Fe} \equiv \mathrm{NR}$ linkage. Of particular interest is the generation and thorough characterization of an $S=1 \mathrm{Fe}^{\mathrm{IV}} \equiv \mathrm{NR}^{+}$imide cation using this new ligand system. The latter species can be observed electrochemically and spectroscopically, and its solid-state crystal structure is reported.
\end{abstract}

Although implicated as intermediates in group transfer reactions, 1 mid-to-late first row transition metals (e.g., $\mathrm{Mn}, \mathrm{Fe}, \mathrm{Co}, \mathrm{Ni}$ ) featuring terminal imido/nitrene functionalities are rare. 2 To date the only examples of structurally characterized mononuclear iron imides are those supported by tris(phosphino)borate ligands. 3 These species have been reported in the $\mathrm{Fe}(\mathrm{III})$ and $\mathrm{Fe}$ (II) oxidation states. In the $\mathrm{Fe}$ (III) state, they have been accessed via oxidative nitrene transfer from organic azides using low valent $\mathrm{Fe}^{\mathrm{I}}$ precursors. The $\left[\mathrm{PhBP}^{\mathrm{R}}{ }_{3}\right] \mathrm{Fe}^{\mathrm{III}}(\mathrm{NR})$ complexes that have been isolated all show electrochemically reversible $\mathrm{Fe}^{\mathrm{III} / \mathrm{II}}$ couples, and chemical reduction typically provides their corresponding $\mathrm{d}^{6}\left\{\left[\mathrm{PhBP}_{3}{ }_{3}\right] \mathrm{Fe}^{\mathrm{II}}(\mathrm{NR})\right\}^{-}$analogues in high yield. Well-defined $\mathrm{Fe}^{\mathrm{IV}}=\mathrm{NR}$ species have proven generally more elusive, ${ }^{4}$ though thoroughly characterized examples of $\mathrm{Fe}^{\mathrm{IV}}=\mathrm{O}$ species are now well known. ${ }^{5}$ To the best of our knowledge the single report of a complex that can be formulated as an $\mathrm{Fe}(\mathrm{IV})$ imide concerns Lee's tetranuclear cluster $\mathrm{Fe}_{4}\left(\mu_{3}-\mathrm{N}^{t} \mathrm{Bu}\right)_{4}\left(\mathrm{~N}^{t} \mathrm{Bu}\right) \mathrm{Cl}_{3}$, isolated in only $1-2 \%$ yield. ${ }^{6}$ Mössbauer data for this species were consistent with a cluster featuring three $\mathrm{Fe}(\mathrm{III})$ centers and one $\mathrm{Fe}$ (IV) center, the latter most likely indicative of the $\mathrm{Fe}^{\mathrm{IV}}=\mathrm{N}^{t} \mathrm{Bu}$ terminal linkage. Herein we describe a new hybrid pyrazolyl/phosphino-borate ligand that can support pseudotetrahedral iron in the $+1,+2,+3$, and +4 oxidation states. The +3 and +4 oxidation states are stabilized by the terminal $\mathrm{Fe} \equiv \mathrm{NR}$ imide linkage.

Access to the required bis(phosphino)pyrazolylborate ${ }^{7}$ ligand is achieved by initial preparation of the bis(phosphino)borane precursor $\mathrm{PhB}\left(\mathrm{CH}_{2} \mathrm{P}^{t} \mathrm{Bu}_{2}\right)_{2}(\mathbf{1})$ via metathesis between $\mathrm{PhBCl}_{2}$ and two equivalents of $\mathrm{LiCH}_{2} \mathrm{P}^{t} \mathrm{Bu}_{2}$ (Scheme 1). Reaction of [pz]Li with $\mathbf{1}$ (pz = pyrazolyl), followed immediately by salt metathesis with $\mathrm{TlPF}_{6}$, leads to the clean formation of solid white $\left[\mathrm{PhBP}^{t \mathrm{Bu}}{ }_{2}(\mathrm{pz})\right] \mathrm{Tl}(\mathbf{2 a})$ in $66 \%$ isolated yield. ${ }^{8}$ The use of the bulky $\mathrm{LiCH}_{2} \mathrm{P}^{t} \mathrm{Bu}_{2}$ carbanion is critically important in the preparation of this type of hybrid borate ligand because (i) effective di- rather than tri-substitution at boron can be achieved, which could not be realized using less hindered carbanions such as $\mathrm{LiCH}_{2} \mathrm{P}^{i} \mathrm{Pr}_{2}$ and $\mathrm{LiCH}_{2} \mathrm{PPh}_{2}$; (ii) the borane product, $\mathrm{PhB}$ $\left(\mathrm{CH}_{2} \mathrm{P}^{t} \mathrm{Bu}_{2}\right)_{2}(\mathbf{1})$, does not appear to dimerize to an appreciable degree in solution. This fact allows the efficient introduction of a third donor arm.

E-mail: jpeters@caltech.edu. 
Metathesis of $\mathbf{2 a}$ with $\mathrm{FeCl}_{2}$ leads to the clean formation of the high spin $(S=2)$ complex $\left[\mathrm{PhBP}^{t \mathrm{Bu}}{ }_{2}(\mathrm{pz})\right] \mathrm{FeCl}(\mathbf{3 a})$, isolated in $69 \%$ yield as a yellow crystalline solid. Solution ${ }^{1} \mathrm{H}$ NMR data for $\mathbf{3 a}$ are suggestive of a monomeric structure in solution, in accord with the calculated solution Evans' method magnetic moment at $295 \mathrm{~K}\left(5.2 \mu_{\mathrm{B}}\right) .{ }^{9}$ However, the $100 \mathrm{~K}$ X-ray crystal structure of $\mathbf{3 a}$ establishes a dimeric structure with bridging chlorides and a crystallographic center of symmetry in the solid-state (see SI for details).

Following an overall methodology that proved effective for the synthesis of $\mathrm{Fe}(\mathrm{III})$ imides previously, one-electron reduction of $\mathbf{3 a}$ with sodium/mercury amalgam in the presence of excess $\mathrm{PMe}_{3}$ generates the high spin $\mathrm{d}^{7}$ precursor $\left[\mathrm{PhBP}^{t \mathrm{Bu}}{ }_{2}(\mathrm{pz})\right] \mathrm{Fe}\left(\mathrm{PMe}_{3}\right)(\mathbf{4 a})$ as a pale green crystalline solid ( $65 \%$ isolated yield; $\mu_{\text {eff }}=4.2 \mu_{\mathrm{B}}$ ). The reaction between $4 \mathbf{a}$ and two equivalents of 1 -adamantylazide $\left(1-\mathrm{AdN}_{3}\right)$ generates the expected $\mathrm{Fe}(\mathrm{III})$ imide $\left[\mathrm{PhBP}^{t B u}{ }_{2}(\mathrm{pz})\right] \mathrm{Fe} \equiv \mathrm{NAd}(\mathbf{5 a})$ as a red-brown low spin species $\left(2.0 \mu_{B}\right.$ in $\left.\mathrm{C}_{6} \mathrm{D}_{6}\right)$, in addition to a stoichiometric equivalent of (1-Ad)N=PMe 3 . The EPR spectrum of $5 \mathbf{a}$ displays a rhombic signal that was simulated (see SI) to provide the g values $g_{1}=2.96, g_{2}=1.95$, and $g_{3}=1.88$ (Figure 1A), a spectrum similar to those of related $\left[\mathrm{PhBP}_{3}\right] \mathrm{Fe}^{\mathrm{III}} \equiv \mathrm{NR}$ imides.

The cyclic voltammetry of $\mathbf{5 a}$ reveals very different features from those observed for $\left[\mathrm{PhBP}_{3}\right] \mathrm{Fe}^{\mathrm{III}}(\mathrm{NR})$ imides (Figure 1B). For example, the cyclic voltammagram of previously reported $\left[\mathrm{PhBP}^{i \mathrm{Pr}}{ }_{3}\right] \mathrm{Fe} \equiv \mathrm{NAd}^{3 \mathrm{~b}}$ features a fully reversible reductive wave at $-1.79 \mathrm{~V}$ and an irreversible oxidative wave at ca. $-0.45 \mathrm{~V}$. This latter process presumably reflects a oneelectron oxidation to an unstable $\mathrm{Fe}(\mathrm{IV})$ species. By contrast, complex $\mathbf{5 a}$ exhibits a completely irreversible reductive wave at $-2.20 \mathrm{~V}$, indicating that the $\mathrm{Fe}(\mathrm{II})$ imide anion is, in this case, unstable. The oxidative irreversible wave at $-1.26 \mathrm{~V}$ appears only after scanning through the $-2.20 \mathrm{~V}$ wave, indicating that it represents a byproduct of the one-electron reduction of $\mathbf{5 a}$.

More interesting, however, is the presence of a quasi-reversible feature at $-0.72 \mathrm{~V}$ for $\mathbf{5 a}$ (at $100 \mathrm{mV} / \mathrm{s} ; 22{ }^{\circ} \mathrm{C}$ ). This wave becomes fully reversible at ambient temperature when the scan rate is increased to $500 \mathrm{mV} / \mathrm{s}$. It represents an $\mathrm{Fe}^{\mathrm{IV} / \mathrm{III}}$ redox couple and suggests that “ $\left\{\left[\mathrm{PhBP}^{t \mathrm{Bu}}{ }_{2}(\mathrm{pz})\right] \mathrm{Fe}^{\mathrm{IV}} \equiv \mathrm{NAd}\right\}^{+} "$ might be modestly stable.

In accord with these electrochemical data, $5 \mathbf{a}$ can be chemically oxidized with $[\mathrm{Fc}]\left[\mathrm{B}\left(\mathrm{Ar}_{\mathrm{F}}\right)_{4}\right]$ $\left(\mathrm{Ar}_{\mathrm{F}}=3,5-\left(\mathrm{CF}_{3}\right)_{2}-\mathrm{C}_{6} \mathrm{H}_{3}\right)$ at low temperature $\left(-50{ }^{\circ} \mathrm{C}\right)$ in THF solution to generate a green, cationic species formulated as $\left\{\left[\mathrm{PhBP}^{t \mathrm{Bu}}{ }_{2}(\mathrm{pz})\right] \mathrm{Fe}^{\mathrm{IV}} \equiv \mathrm{NAd}\right\}\left\{\mathrm{B}\left(\mathrm{Ar}_{\mathrm{F}}\right)_{4}\right\}(\mathbf{6 a})$. A single set of paramagnetic resonances is observed for $6 \mathbf{a}$ in its ${ }^{1} \mathrm{H}$ NMR spectrum at $-50{ }^{\circ} \mathrm{C}$ (see SI), distinct from the resonances observed for 5a. Using an optical dip-probe assembly, the appearance of absorption bands at $580 \mathrm{~nm}$ and $677 \mathrm{~nm}$ are readily observed at low temperature upon addition of the ferrocenium oxidant (see SI). We also established that the addition of 1 equiv of $\mathrm{CoCp}_{2}$ to $6 \mathbf{a}$ generated in situ in THF- $d_{8}$ solution regenerated 5a cleanly. The half-life of $6 \mathbf{a}$ is approximately $50 \mathrm{~min}$ at $-40{ }^{\circ} \mathrm{C}$ in THF- $d_{8}$ and it must therefore be manipulated at temperatures below $-40{ }^{\circ} \mathrm{C}$. Solution magnetic data collected at low temperature $\left(\mu_{\text {eff }}=3.1(2)\right.$ $\mu_{B}$ in THF- $\mathrm{d}_{8}, 222 \mathrm{~K}$; avg of 4 runs) indicate two unpaired electrons $(S=1)$, consistent with the ground state electronic configuration $\left(\mathrm{d}_{\mathrm{z}} 2\right)^{2}\left(\mathrm{~d}_{\mathrm{xy}}\right)^{1}\left(\mathrm{~d}_{\mathrm{x}}{ }^{2}-\mathrm{y}^{2}\right)^{1}\left(\mathrm{~d}_{\mathrm{xz}}\right)^{0}\left(\mathrm{~d}_{\mathrm{yz}}\right)^{0}$.

We undertook a crystallographic investigation of $\mathbf{5 a}$ and $\mathbf{6 a}$ to confirm their connectivities and to examine their $\mathrm{Fe}-\mathrm{N}$ bond distances and $\mathrm{Fe}-\mathrm{N}_{\text {imide }}-\mathrm{C}$ bond angles for comparison with $\left[\mathrm{PhBP}_{3}{ }_{3}\right] \mathrm{Fe} \equiv \mathrm{NR}$ imides. For the case of $\mathbf{5 a}$, the crystals that we obtained were twinned, regardless of the method employed for crystallization. Its structure could nonetheless be refined isotropically to confirm its pseudotetrahedral geometry (see SI). Evident from its isotropic structure is an expectedly short Fe- $\mathrm{N}_{\text {imide }}$ bond distance $(1.63 \AA$ ) and a nearly linear C-N3-Fe angle $\left(169^{\circ}\right) .^{3}$

Owing to the thermal instability of $\mathbf{6 a}$, its XRD analysis proved to be a more challenging experiment. Single green crystals could be obtained by storing a THF/petroleum ether solution 
at $-78{ }^{\circ} \mathrm{C}$ for several days, and XRD analysis confirmed its proposed assignment (see SI). To obtain a better quality data set we set out to prepare an analogue of $\mathbf{6 a}$ of greater kinetic stability. We thus pursued a $\left[\mathrm{PhBP}^{t \mathrm{Bu}}{ }_{2}\left(\mathrm{pz}^{\prime}\right)\right]^{-}$derivative substituted by methyl groups at the 3 and 5 positions. The required precursor $\left(\left[\mathrm{PhBP}^{t \mathrm{Bu}}{ }_{2}\left(\mathrm{pz}^{\mathrm{Me} 2}\right)\right] \mathrm{Tl}, \mathbf{2 b}\right)$ and an analogous series of iron complexes $(\mathbf{3 b}-\mathbf{6 b}$, Scheme 1) were readily prepared by the same procedures described above. The imide cation $\mathbf{6 b}$ indeed exhibits far greater thermal stability than $\mathbf{6 a}$. It's cyclic voltammetry is very similar to that of $\mathbf{6 a}$, and the $\mathrm{Fe}^{\mathrm{IV} / \mathrm{III}}$ redox couple is reversible even at slower scan rates (e.g., $100 \mathrm{mV} / \mathrm{s}$ ). $\mathbf{6 b}$ can even be isolated in pure form at ambient temperature (86.7\% yield) and manipulated without appreciable degredation for short periods. X-ray data sets were obtained for $\mathbf{5 b}$ (disordered structure; see $\mathrm{SI}$ ) and $\mathbf{6 b}$. The anisotropically refined $\mathrm{X}$ ray crystal structure of $\left\{\left[\mathrm{PhBP}^{t \mathrm{Bu}}{ }_{2}\left(\mathrm{pz}^{\mathrm{Me} 2}\right)\right] \mathrm{Fe}^{\mathrm{IV}} \equiv \mathrm{NAd}\right\}\left\{\mathrm{B}\left(\mathrm{Ar}_{\mathrm{F}}\right)_{4}\right\} \mathbf{6} \mathbf{b}$ is shown in Figure 2. The structure reveals the anticipated pseudotehedral iron cation and its tetra(aryl)borate counter-anion. The Fe-N3 bond distance (1.634(4) $\AA$ ) and the $\mathrm{Fe}-\mathrm{N}_{\text {imide }}-\mathrm{C}$ bond angle (176.2 $\left.(3)^{\circ}\right)$ are similar to the parameters obtained for crystallographically characterized $\left[\mathrm{PhBP}_{3}\right] \mathrm{Fe}$ imides in the +3 and +2 oxidation states. Assuming that the two unpaired electrons of $\mathbf{6 b}$ reside in relatively nonbonding d-orbitals, as predicted from simple $\mathrm{MO}$ considerations, ${ }^{2 b}, 3 \mathrm{c}$ the $\mathrm{Fe}$ -

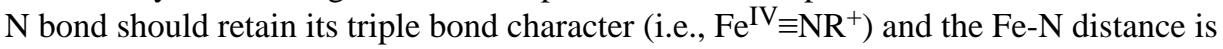
therefore not expected to change to a large extent upon oxidation.

To conclude, we have introduced the hybrid phosphine/pyrazole borate ligands $\left[\mathrm{PhBP}^{t \mathrm{Bu}}{ }_{2}(\right.$ $\left.\left.\mathrm{pz}^{\prime}\right)\right]^{-}$, and begun to explore their utility in the context of nitrene group transfer to iron. Whereas iron imides had been previously obtained in the +3 and +2 oxidation states using $\left[\mathrm{PhBP}_{3}{ }_{3} \mathrm{Fe}\right.$ systems, we now find that imides in the +3 and +4 oxidation states are accessible using $\left[\mathrm{PhBP}^{t \mathrm{Bu}}{ }_{2}\left(\mathrm{pz}^{\prime}\right)\right] \mathrm{Fe}$ systems. It is remarkable that terminally bonded $\mathrm{L}_{3} \mathrm{Fe} \equiv \mathrm{NR}$ species have now been characterized in three distinct oxidation states using phosphine-borate ligands given the paucity of such species more generally. The cause of the increased stability of the $\mathrm{Fe}^{\mathrm{IV}} \equiv \mathrm{NR}$ linkage in the $\left[\mathrm{PhBP}^{t \mathrm{Bu}}{ }_{2}\left(\mathrm{pz}^{\prime}\right)\right] \mathrm{Fe}$ system described herein is an interesting issue and might in part be attributed to (i) a cathodic shift in the $\mathrm{Fe}^{\mathrm{IV} / \mathrm{III}}$ potential by comparison to previous $\left[\mathrm{PhBP}_{3}\right] \mathrm{Fe}$ imide systems, which in turn might lend added stability to the ligand borate unit; (ii) and/or to the lower symmetry of the $\left[\mathrm{PhBP}^{t B u}{ }_{2}\left(\mathrm{pz}^{\prime}\right)\right]$ ligand, and the compatibility of this lower symmetry with a $\mathrm{d}^{4}$ triplet electronic configuration.

\section{Supplementary Material}

Refer to Web version on PubMed Central for supplementary material.

\section{Acknowledgments}

We acknowledge Larry Henling for crystallographic assistance and Dr. Mark Mehn for assistance with EPR spectroscopy. We thank the NIH for financial support (GM 070757), and NPM is grateful for an NSF graduate fellowship.

\section{References}

1. (a) Li Z, Conser KR, Jacobsen EN. J. Am. Chem. Soc 1993;115:5326. (b) Evans DA, Faul MM, Bilodeau MT. J. Am. Chem. Soc 1994;116:2742. (c) DuBois J, Tomooka CS, Hong J, Carreira EM. Acc. Chem. Res 1997;30:364. (d) Wigley DE. Progress in Inorganic Chemistry 1994;Vol. 42:239482. (e) Eikey RA, Abu-Omar MM. Coord. Chem. Rev 2003;243:83.

2. For recent examples see: (a) Mindiola DJ, Hillhouse GL. J. Am. Chem. Soc 2001;123:4623. [PubMed: 11457258] (b) Jenkins DM, Betley TA, Peters JC. J. Am. Chem. Soc 2002;124:5272. [PubMed: 11996560] (c) Eikey RA, Khan SI, Abu-Omar MM. Angew. Chem. Int. Ed 2002;41:3592. (d) Dai X, Kapoor P, Warren TH. J. Am. Chem. Soc 2004;126:4798. [PubMed: 15080682] (e) Hu X, Meyer K. J. Am. Chem. Soc 2004;126:16322. [PubMed: 15600324] 
3. (a) Brown SD, Betley TA, Peters JC. J. Am. Chem. Soc 2003;125:322. [PubMed: 12517130] (b) Betley TA, Peters JC. J. Am. Chem. Soc 2003;125:10782. [PubMed: 12952446] (c) Brown SD, Peters JC. J. Am. Chem. Soc 2004;126:4538. [PubMed: 15070370] (d) Brown SD, Peters JC. J. Am. Chem. Soc 2005;127:1913. [PubMed: 15701026]

4. Fe(IV) imides have been implicated as intermediates in nitrene transfer reactions: (a) Lucas RL, Powell DR, Borovik AS. J. Am. Chem. Soc 2005;127:11596. [PubMed: 16104724] (b) Jensen MP, Mehn MP, Que L Jr. Angew. Chem. Int. Ed 2003;42:4357.

5. For recent non-heme iron examples see: (a) Rohde J-U, In J-H, Lim MH, Brennessel WW, Bukowski MR, Stubna A, Münck E, Nam W, Que L Jr. Science 2003;299:1037. [PubMed: 12586936] (b) Klinker EJ, Kaiser J, Brennessel WW, Woodrum NL, Cramer CJ, Que L Jr. Angew. Chem. Int. Ed 2005;44:3690. (c) Bukowski MR, Koehntop KD, Stubna A, Bominaar EL, Halfen JA, Münck E, Nam W, Que L Jr. Science 2005;310:1000. [PubMed: 16254150] (d) Grapperhaus CA, Mienert B, Bill E, Weyhermuller T, Wieghardt K. Inorg. Chem 2000;39:5306. [PubMed: 11187471]

6. Verma AK, Nazif TN, Achim C, Lee SC. J. Am. Chem. Soc 2000;122:11013.

7. A related bis(pyrazole)(phosphine)borate ligand was reported recently: Casado MA, Hack V, Camerano JA, Ciriano MA, Tejel C, Oro LA. Inorg. Chem 2005;44:9122. [PubMed: 16323887]

8. In this paper we adopt the ligand abbreviations $\left[\mathrm{PhBP}^{t \mathrm{Bu}}{ }_{2}(\mathrm{pz})\right]$ and $\left[\mathrm{PhBP}^{t \mathrm{Bu}}{ }_{2}\left(\mathrm{pz}^{\mathrm{Me} 2}\right)\right]$ to refer to a parent pyrazole and a 3,5-dimethyl substituted derivative, respectively. $\left[\mathrm{PhBP}^{t \mathrm{Bu}}{ }_{2}\left(\mathrm{pz}^{\prime}\right)\right]$ is a general notation to represent any pyrazole derivative

9. (a) Sur SK. J. Magn. Reson 1989;82:169. (b) Evans DF. J. Chem. Soc 1959:2003. 
A

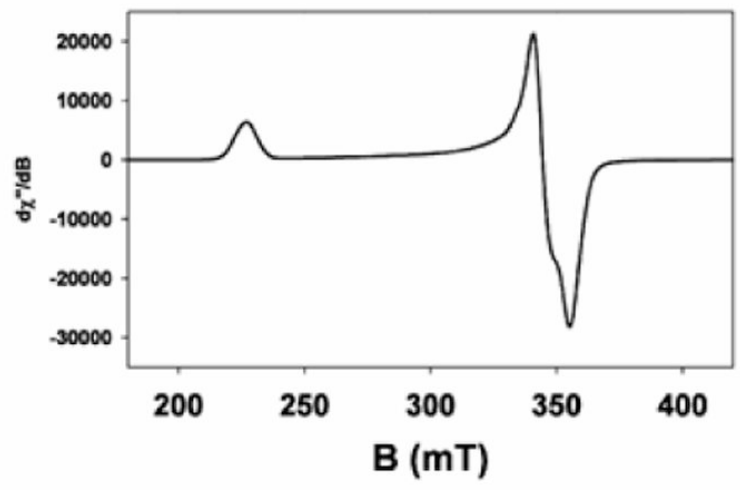

B

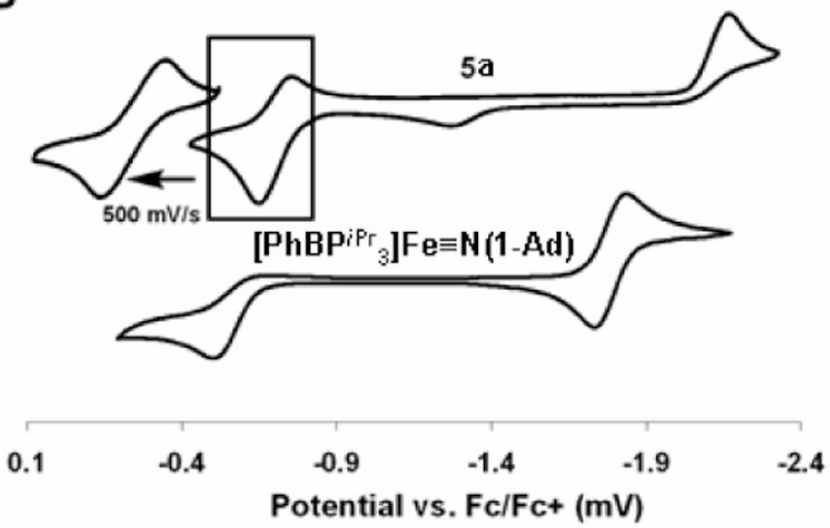

Figure 1.

(A) EPR spectrum of 5a with $g_{1}=2.96, g_{2}=1.95$, and $g_{3}=1.88$ (in 2-methyltetrahydrofuran glass at $20 \mathrm{~K}, 9.474 \mathrm{GHz})$. (B) Cyclic voltammetry of $\mathbf{5 a}\left(0.40 \mathrm{M}\left[{ }^{\mathrm{n}} \mathrm{BuN}_{4}\right]\left[\mathrm{ClO}_{4}\right]\right.$ in $\mathrm{THF}$, scan rate $=100 \mathrm{mV} / \mathrm{s}$ (full), $500 \mathrm{mV} / \mathrm{s}$ (inset)), and $\left[\mathrm{PhBP}^{i \mathrm{Pr}}{ }_{3}\right] \mathrm{Fe} \equiv \mathrm{NAd}\left(0.40 \mathrm{M}\left[{ }^{\mathrm{n}} \mathrm{BuN}_{4}\right]\left[\mathrm{PF}_{6}\right]\right.$ in THF). 


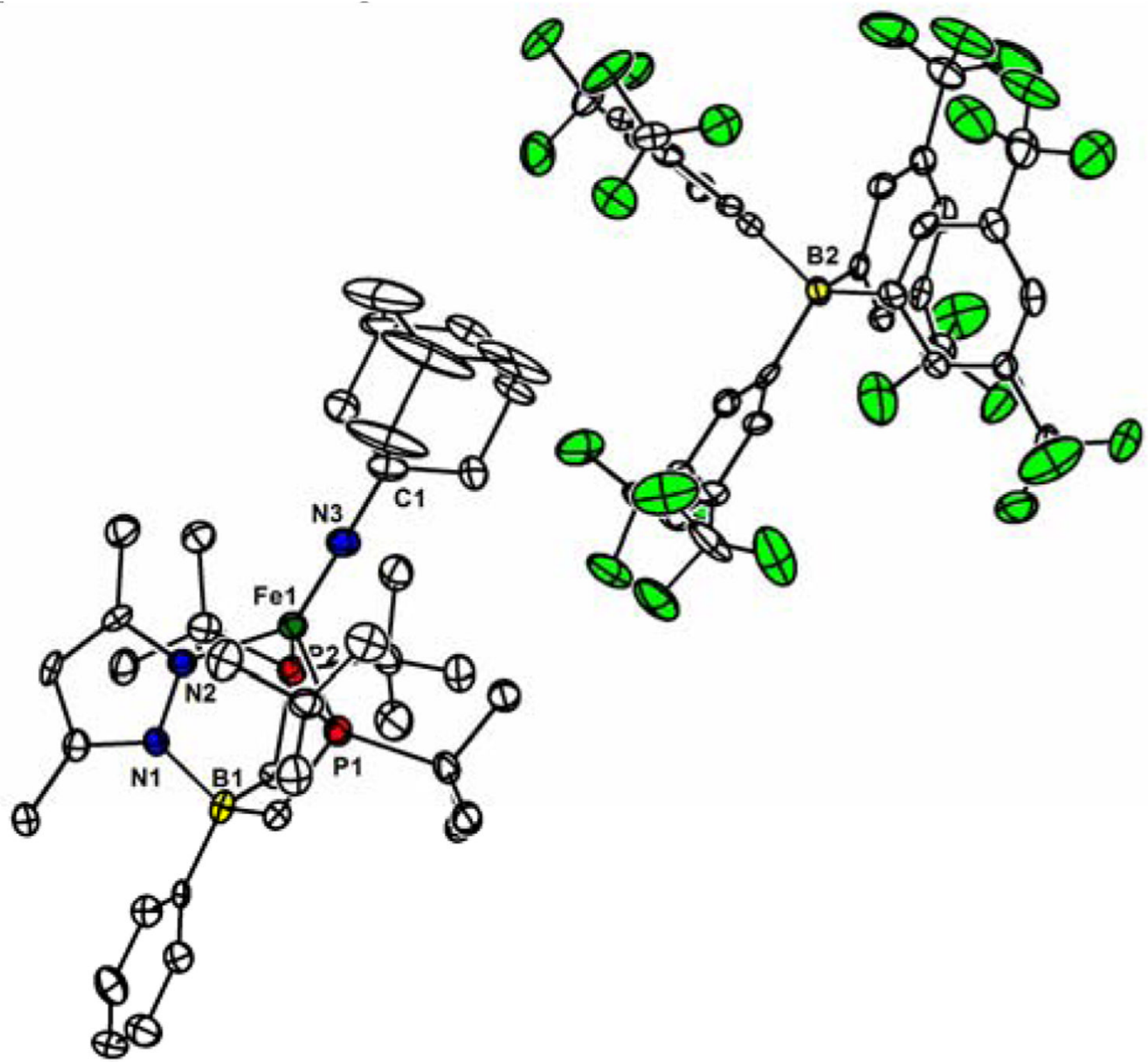

Figure 2.

Anisotropically refined thermal ellipsoid representation of $\left\{\left[\mathrm{PhBP}^{t \mathrm{Bu}}{ }_{2}\left(\mathrm{pz}^{\mathrm{Me} 2}\right)\right] \mathrm{Fe} \mathrm{IV}_{\equiv \mathrm{NAd}}\right\}$ $\left\{\mathrm{B}\left(\mathrm{Ar}_{\mathrm{F}}\right)_{4}\right\}(\mathbf{6 b})$; two molecules of THF and all hydrogen atoms have been omitted for clarity; Fe-N3: 1.634(4) $\AA$, Fe-N3-C1: 176.2(3) . 

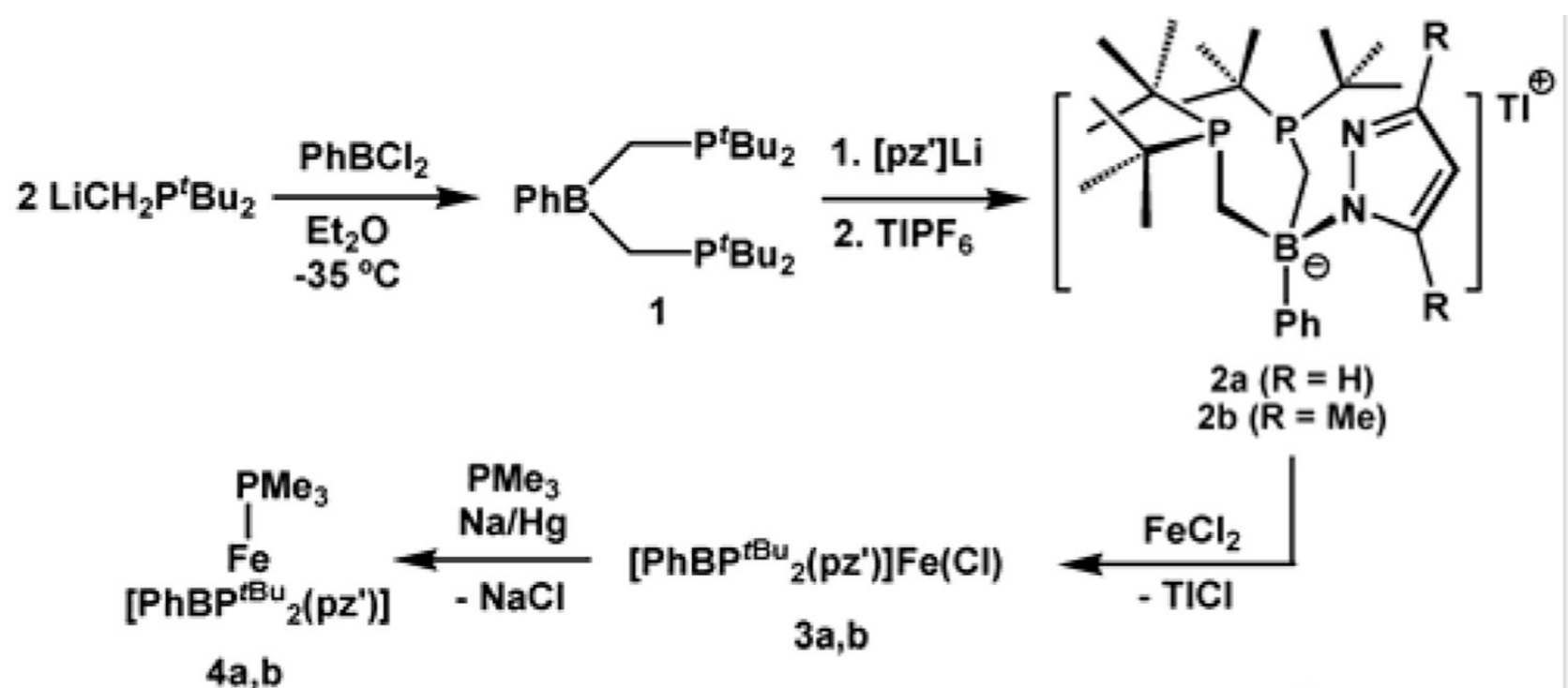

$4 a, b$
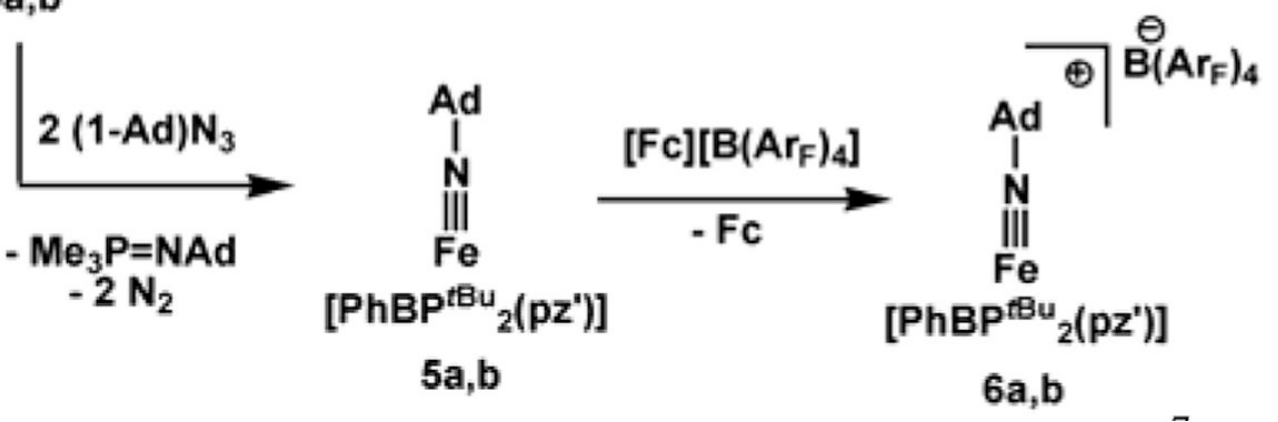

Scheme 1. 